\title{
Subglacial bedforms reveal complex basal regime in a zone of paleo- ice stream convergence, Amundsen Sea embayment, West Antarctica
}

\author{
Robert D. Larter ${ }^{1}$, Alastair G.C. Graham¹, Karsten Gohl², Gerhard Kuhn², Claus-Dieter Hillenbrand ${ }^{1}$, James A. Smith ${ }^{1}$, \\ Tara J. Deen ${ }^{1}$, Roy A. Livermore ${ }^{1}$, and Hans-Werner Schenke ${ }^{2}$ \\ 'British Antarctic Survey, High Cross, Madingley Road, Cambridge CB3 OET, UK \\ ${ }^{2}$ Alfred Wegener Institut für Polar und Meeresforschung, Postfach 120161, D-27515 Bremerhaven, Germany
}

\begin{abstract}
The flow of ice streams, which account for most discharge from large ice sheets, is controlled by processes operating at the ice stream bed. Data from modern ice stream beds are difficult to obtain, but where ice advanced onto continental shelves during glacial periods, extensive areas of the former bed can be imaged using modern swath sonar tools. We present new multibeam swath bathymetry data analyzed alongside sparse preexisting data from the Amundsen Sea embayment. The compilation is the most extensive, continuous area of multibeam data coverage yet obtained on the inner continental shelf of Antarctica. The data reveal streamlined subglacial bedforms that define a zone of paleo-ice stream convergence, but, in contrast to previous models, do not show a simple downflow progression of bedform types along paleo-ice stream troughs. We interpret high spatial variability of bedforms as indicating a complex mechanical and hydrodynamic regime at the former ice stream beds, consistent with observations from some modern ice streams. We conclude that care must be taken when using bedforms to infer paleo-ice stream velocities.
\end{abstract}

\section{INTRODUCTION}

The Intergovernmental Panel on Climate Change (IPCC, 2007) has highlighted future changes in the dynamics of large ice sheets as the largest uncertainty in sea level-rise projections. Understanding processes that control ice discharge is therefore of societal and economic importance. Ice discharge from the Antarctic and Greenland ice sheets occurs mainly through fast-flowing ice streams (Bamber et al., 2007). Geophysical and drilling investigations of mechanisms at ice-stream beds that enable streaming flow have been conducted over more than two decades (e.g., Alley et al., 1986; Engelhardt and Kamb, 1998; Smith et al., 2007), but have been limited by inaccessibility of field sites and the difficulty of investigating an interface buried beneath hundreds of meters of ice.

Although investigating modern ice sheet beds is difficult, pristine subglacial bedforms from a formerly more extensive ice sheet are preserved in many deep troughs on the Antarctic continental shelf, and large areas of the former ice base can be imaged using modern swath sonar tools (Pudsey et al., 1994; Canals et al., 2000; Wellner et al., 2001, 2006; Ó Cofaigh et al., 2002).

Wellner et al. (2001) described a typical progression of bedform types along paleo-ice flow paths, from grooves, roches moutonnées, and subglacial meltwater channels on the inner shelf, through a zone of drumlins associated with a transition from crystalline to sedimentary substrates, to mega-scale glacial lineations on the outer shelf. Furthermore, Wellner et al. $(2001,2006)$ interpreted this progression of bedform types as being associated with accel- erating ice flow rates, with the zone of drumlins marking the onset of streaming flow. Ó Cofaigh et al. (2002) showed that extensive multibeam swath bathymetry data collected along Marguerite trough, Antarctic Peninsula, was generally consistent with this model.

Here we present new multibeam swath bathymetry data collected from the Amundsen Sea embayment, compiled with sparse preexisting data, covering the most extensive, continuous area $\left(9950 \mathrm{~km}^{2}\right)$ yet imaged on the inner continental shelf around Antarctica. We describe subglacial bedforms that indicate a zone of paleo-ice stream convergence, and interpret the high spatial variability in seafloor morphology as indicating a complex regime at the former ice base.

\section{PREVIOUS WORK IN THE AMUNDSEN SEA EMBAYMENT}

Approximately 25\% of the area of the West Antarctic Ice Sheet (WAIS) drains into the Amundsen Sea embayment (Fig. 1). Hughes (1981) suggested that the Amundsen Sea embayment sector is the most likely site for initiation of WAIS collapse. This remains a concern today (Vaughan, 2008), but relatively little is known about the history of the major glacial systems in the Amundsen Sea embayment sector.

Wellner et al. (2001) published the first multibeam bathymetry and seismic reflection data from the Amundsen Sea embayment, and recognized that there was a change in subglacial morphology associated with a substrate transition from acoustic basement on the inner shelf to sedimentary strata further offshore. Additional geophysical data and sediment cores from a large cross-shelf trough that extends offshore from Pine Island Bay (Fig. 1) were interpreted by Lowe and Anderson $(2002,2003)$ as showing that grounded ice had extended onto the outer shelf during the last glacial cycle. From radiocarbon dates on calcareous microfossils in sediment cores, Lowe and Anderson (2002) concluded that ice retreated from the outer shelf prior to ca. $16 \mathrm{ka}\left({ }^{14} \mathrm{C} \mathrm{yr}\right)$ and had retreated to the inner shelf by $12 \mathrm{ka}$. Evans et al. (2006) presented multibeam data showing streamlined bedforms that extend to the shelf edge in a trough at $114^{\circ} \mathrm{W}$, and argued that their characteristics suggested that the WAIS was grounded to the shelf edge during the Last Glacial Maximum (LGM).

\section{DATA ACQUISITION}

Multibeam echo-sounding data were collected on RRS James Clark Ross and RV Polarstern in early 2006. On James Clark Ross a Kongsberg EM120 system with 191 beams in the range 11.25-12.75 kHz was used, and on Polarstern, an Atlas Hydrosweep DS-2 system with 59 beams at $15.5 \mathrm{kHz}$ was used. Beam raypaths and seafloor depths were calculated in near real time using sound velocity profiles derived from conductivitytemperature-depth casts on the same cruises. Processing consisted of rejecting outlying values and gridding using a near-neighbor algorithm. Sparse, preexisting multibeam data were included in the grid (GSA Data Repository item DR $1^{1}$ ). Subbottom echo sounder profiles were collected along all survey lines. Navigation data were acquired using the global positioning system.

\section{GENERAL PHYSIOGRAPHY}

In the western Amundsen Sea embayment, three 17-39-km-wide troughs extend seaward from modern ice shelf fronts (Figs. 1, 2, and Fig. DR2). Within $70 \mathrm{~km}$ of the ice fronts these troughs merge northward into a single trough that is $65 \mathrm{~km}$ wide at $600 \mathrm{~m}$ depth (Larter et al., 2007; Nitsche et al., 2007). This trough becomes shallower with increasing distance offshore, but

${ }^{1}$ GSA Data Repository item 2009104, multibeam bathymetry grid, large map display of multibeam batyhmetry grid, examples of subbottom echo sounder profiles, subbottom echo-sounder profile data, is available online at www.geosociety.org/pubs/ $\mathrm{ft} 2009 . \mathrm{htm}$, or on request from editing@ geosociety. org or Documents Secretary, GSA, P.O. Box 9140 , Boulder, CO 80301, USA. 
continues northwest to the shelf edge where its axis, between $118^{\circ}$ and $119^{\circ} \mathrm{W}$, is still deeper than $500 \mathrm{~m}$ (Figs. 1 and 3).

The easternmost tributary trough extends from the Dotson Ice Shelf and the other two extend from parts of the Getz Ice Shelf either side of Wright Island. We refer to them as, from east to west, the Dotson, Getz A, and Getz B troughs. These troughs are all more than $1000 \mathrm{~m}$ deep at the modern ice fronts.

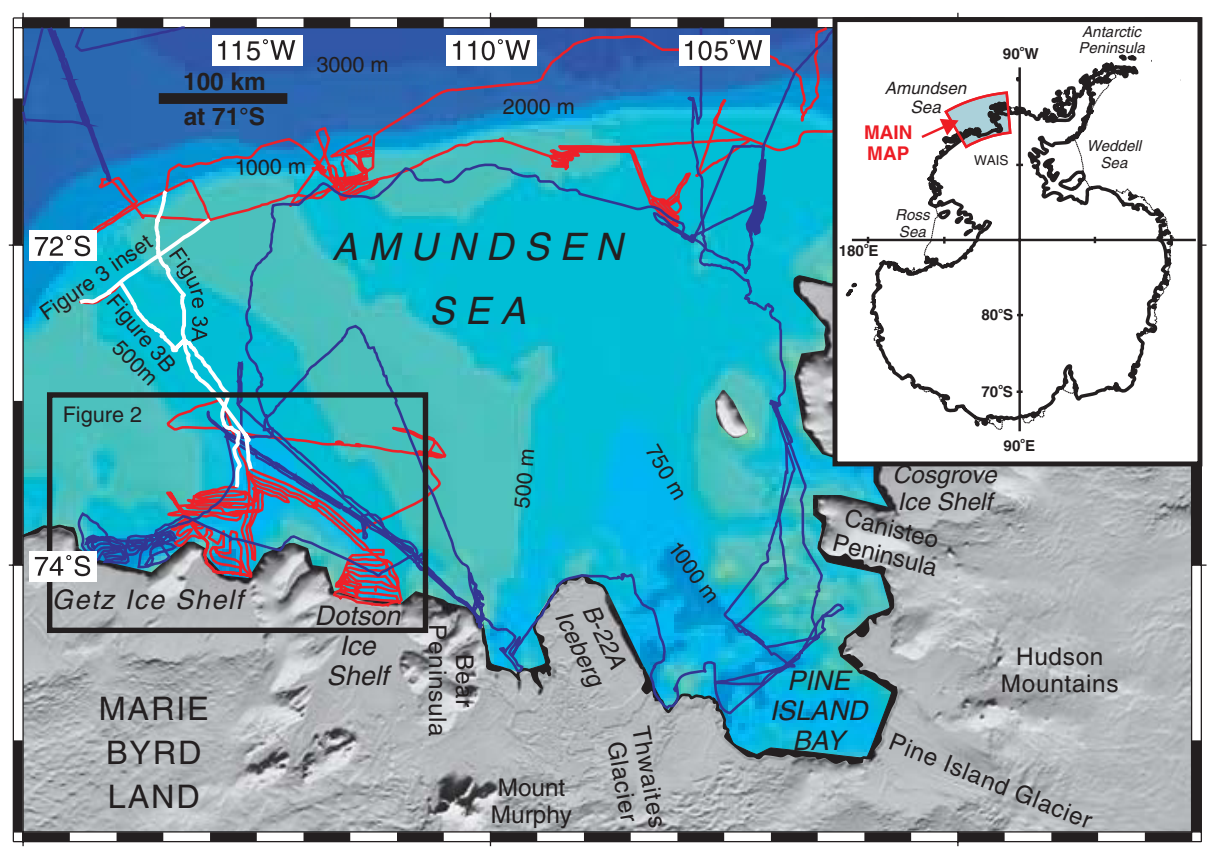

Figure 1. Amundsen Sea embayment map showing tracks of 2006 cruises on RRS James Clark Ross (red) and RV Polarstern (blue). Regional bathymetry from Nitsche et al. (2007). Moderate resolution imaging spectroradiometer (MODIS) mosaic of Antarctica is shown in onshore areas. Box indicates location of Figure 2. White lines indicate locations of profiles in Figure 3. Inset shows location of main map.

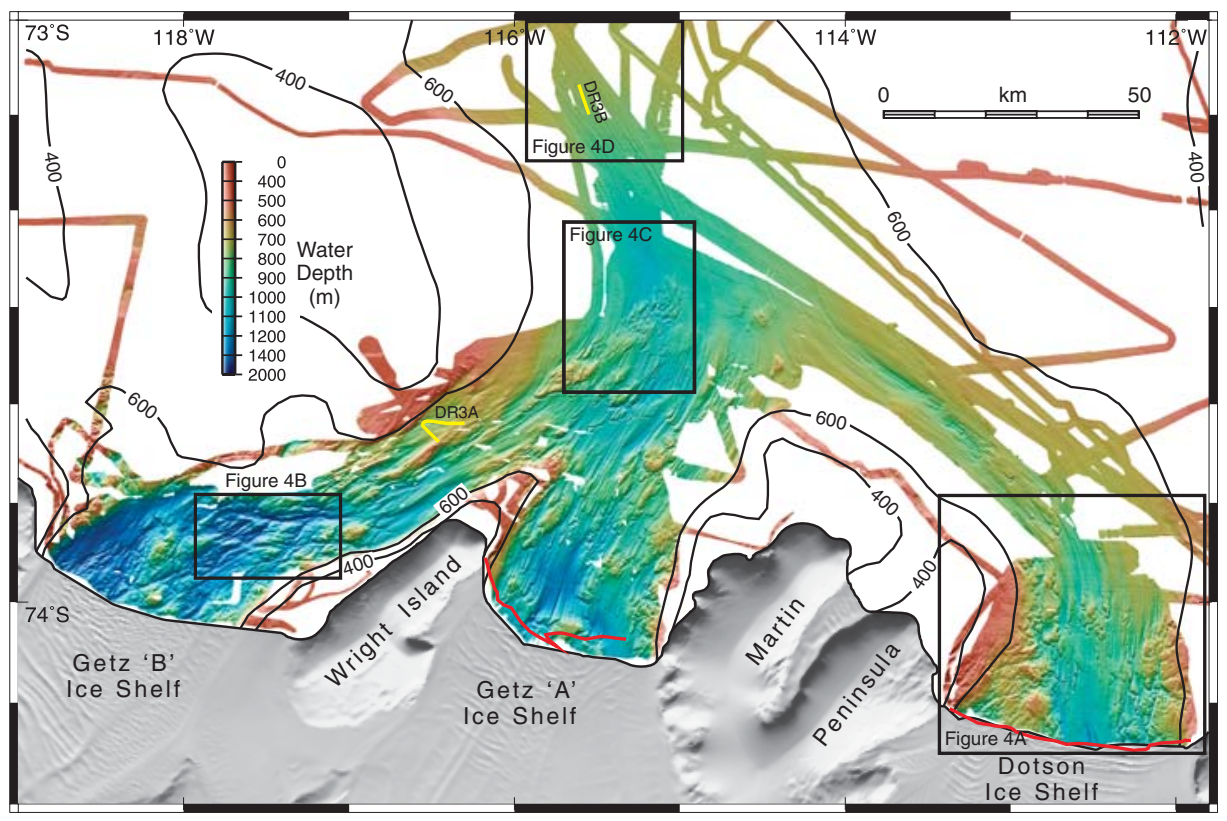

Figure 2. Multibeam swath bathymetry data in western Amundsen Sea embayment, illuminated from northwest. Grid cell size is $50 \mathrm{~m}$. Boxes indicate locations of data panels in Figure 4. Yellow lines indicate locations of profiles in Figure DR3 (see footnote 1). Regional $400 \mathrm{~m}$ and 600 $\mathrm{m}$ bathymetry contours from Nitsche et al. (2007) show general form of seafloor beyond multibeam data limits. Moderate resolution imaging spectroradiometer (MODIS) mosaic of Antarctica is shown in onshore areas (cropped along ice shelf fronts to avoid obscuring multibeam data). Red lines indicate January 2006 positions of Dotson and Getz A ice fronts.

\section{SUBGLACIAL BEDFORMS}

Elongated bedforms revealed by the multibeam data are aligned parallel to the axes of the tributary troughs and show overall convergence with increasing distance from the ice margin (Fig. 2). The data show a large amount of variability in seafloor morphology across, along, and between the troughs. The morphology in the southern part of the Getz B trough is markedly different from that in the other two.

In the southernmost Dotson trough, within 30 $\mathrm{km}$ of the 2006 ice front, the range of bedforms observed includes irregular scours, linear grooves, drumlins, mega-scale glacial lineations, and channels with variable orientations and undulating thalwegs (Fig. 4A). The streamlined bedforms have elongation ratios ranging from 3.5:1 to 40:1. Clusters of drumlins are spread across the trough axis $20-25 \mathrm{~km}$ north of the ice front, and $\sim 20 \mathrm{~km}$ farther north, where both the trough axis and the elongation direction of bedforms have rotated to a northwest trend. Farther northwest, mega-scale glacial lineations are the dominant bedforms along the axis of the Dotson trough, but continue to be interspersed with drumlins (Fig. 2).

The Getz A trough within $30 \mathrm{~km}$ of the 2006 ice front exhibits a range of bedforms similar to that observed in the Dotson trough. Streamlined bedforms with a range of elongation ratios similar to those in the Dotson trough are the dominant bedforms in the central $25 \mathrm{~km}$ of the Getz A trough, although isolated, scoured highs, some with amplitudes exceeding $300 \mathrm{~m}$, also occur within this zone (Fig. 2). Approximately $30 \mathrm{~km}$ north of the ice front, a zone of drumlins and grooves occurs on a sill that extends across the trough and rises to $<900 \mathrm{~m}$ (Fig. 2).

In addition to bedforms indicative of glacial overriding, the southern part of the Getz B trough also exhibits a range of bedforms suggestive of erosion by flowing water. Anastomosing channels are the dominant bedforms in the central part of the trough within $25 \mathrm{~km}$ of the ice front. Many of the channels have undulating thalwegs, and the network of channels extends over highs within the trough that rise more than $300 \mathrm{~m}$ above its floor (Fig. 2). The largest channels (as wide as $4500 \mathrm{~m}$, incised to $450 \mathrm{~m}$ ) merge eastward in a dendritic pattern, and some contain meanders (Fig. 4B). There is a transition to northeast-trending, elongated drumlins and mega-scale glacial lineations as the dominant bedforms in the trough $35-40 \mathrm{~km}$ northeast of the ice front (Fig. 2). Some of the mega-scale glacial lineations continue across a broad sill at the mouth of the Getz B trough, parts of which rise to $<700 \mathrm{~m}$ (Fig. 2). This sill is colinear with the one at the mouth of the Getz A trough.

In the $35 \mathrm{~km}$ to the north of the sills, megascale glacial lineations are interrupted by further bands of scoured highs and drumlins. There is an abrupt northern limit to this zone of varied bed- 


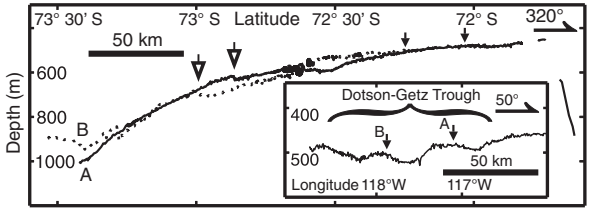

Figure 3. Bathymetric profiles along Dotson-Getz trough. Open arrows mark short seaward-inclined ramps. Inset shows profile across outer shelf part of trough, with vertical scale expanded compared to main figure. Small filled arrows mark intersections of profiles A and B with the cross-trough profile. Profile locations are shown in Figure 1. Scale bars represent distances along and across trough when profiles are projected in true geographic directions indicated in top right of figure and inset.

forms at $\sim 73^{\circ} 30^{\prime} \mathrm{S}$, beyond which mega-scale glacial lineations are the only bedforms in the next $40 \mathrm{~km}$ along the trough (Figs. 2 and 4C). Seismic profiles show that this boundary coincides with a change in substrate from acoustic basement to the south to northward-dipping sedimentary strata to the north (Wellner et al., 2001; Larter et al., 2007). Subbottom profiler data show either no seafloor penetration or very thin sediment cover everywhere to the south of this boundary (Fig. DR3A), suggesting that the observed bedforms are eroded into or directly overlie bedrock.

As the main Dotson-Getz trough shallows northward, randomly oriented furrows cutting across mega-scale glacial lineations are encountered at $760 \mathrm{~m}$ depth (Fig. 4D). Such furrows are characteristic of ploughing by iceberg keels (Barnes and Lien, 1988; Pudsey et al., 1994). Shallower than $700 \mathrm{~m}$, only $20 \mathrm{~km}$ farther north along the trough axis, mega-scale glacial lineations are completely obliterated by iceberg furrows.

The Dotson-Getz trough continues to shallow northward all the way to the shelf break (Fig. 1; Nitsche et al., 2007), with an average gradient of $0.08^{\circ}$ (Fig. 3). On each profile shown in Figure 3 , the only interruption to this northward shoaling is one $<30$-m-high, seaward-inclined ramp near $73^{\circ} \mathrm{S}$. These profiles preclude the existence of any large grounding zone wedges or moraine banks farther seaward on the shelf that could plausibly be interpreted as marking the limit of LGM grounding line advance (cf. Shipp et al., 1999; O’Brien et al., 1999). This is consistent with the interpretation that the grounding line in the Amundsen Sea embayment advanced to the shelf edge (Evans et al., 2006). The cross-trough profile in the inset in Figure 3 demonstrates that the trough continues across the outer shelf, albeit with a relief of only $\sim 70 \mathrm{~m}$.

\section{DISCUSSION AND CONCLUSIONS}

Bedform elongation ratios of as much as 40:1 close to the modern ice fronts in the Dotson and

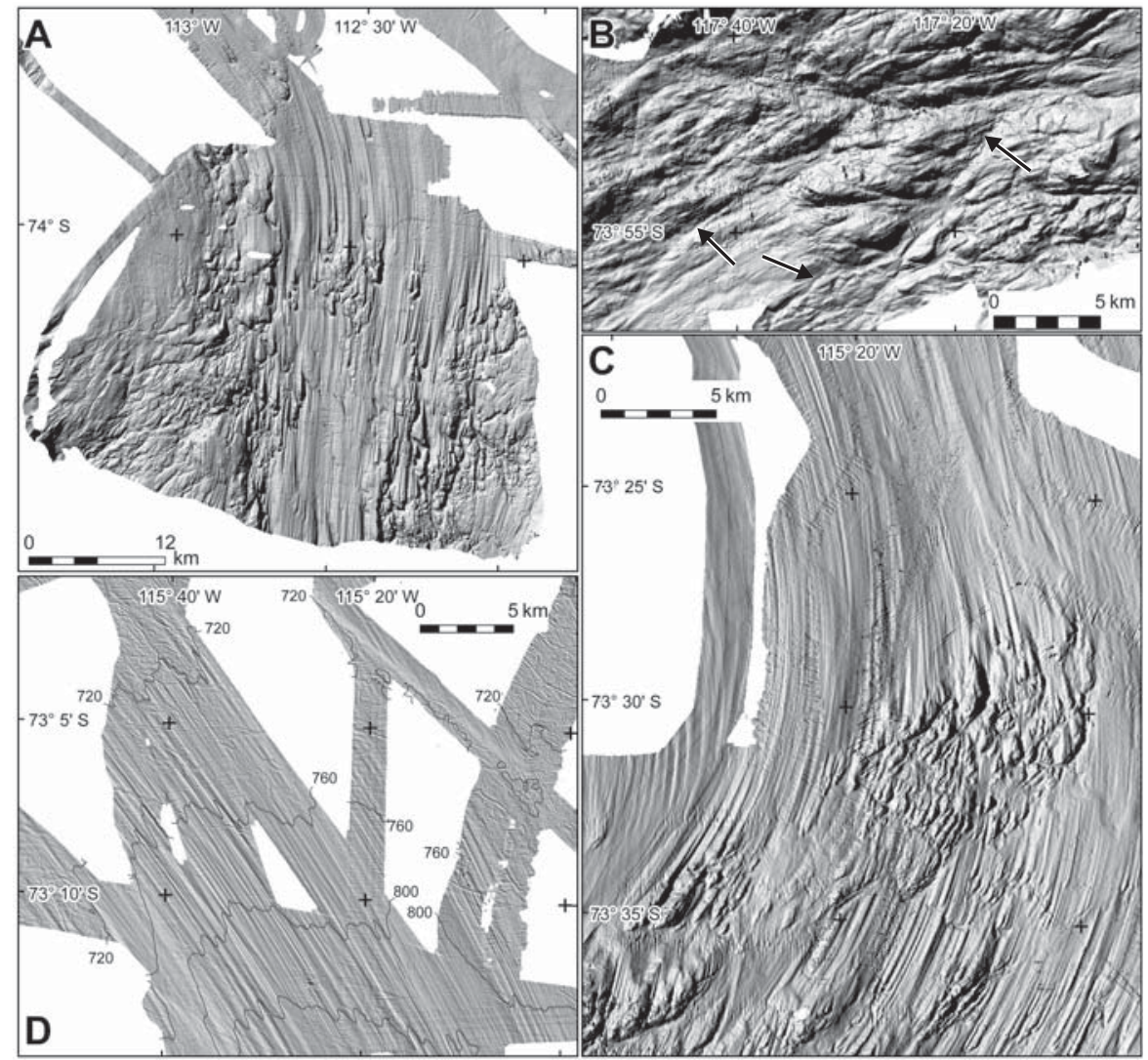

Figure 4. Shaded relief images of selected multibeam bathymetry data areas. Grid cell size is $\mathbf{3 0}$ $\mathrm{m}$, projected in Universal Transverse Mercator zone 11S. Locations are shown in Figure 2. A and $B$ are illuminated from northwest, $C$ from west, $D$ from northeast; all with $45^{\circ}$ elevation. A: Varied bedforms in Dotson trough. B: Channels in Getz B trough; arrows mark meanders. C: Boundary between zone of varied bedforms and zone containing only mega-scale glacial lineations (MSGL), which coincides with substrate boundary in seismic profiles. D: Transition from MSGL to iceberg furrows in Dotson-Getz trough, with bathymetric contours at $\mathbf{4 0} \mathrm{m}$ intervals.

Getz A tributary troughs indicate that paleo-ice streams flowed along them during the last glacial period (cf. Canals et al., 2000; Ó Cofaigh et al., 2002; Stokes and Clark, 2002). Similarly elongated bedforms, within $40 \mathrm{~km}$ of the Getz $\mathrm{B}$ ice front, indicate that streaming flow also occurred at least in the northeast part of that tributary trough. The pattern of bedforms indicates flow convergence northward, which necessarily also implies flow acceleration.

Using sparser multibeam bathymetry data, Wellner et al. (2001) suggested that initiation of streaming flow was coincident with the change in substrate at $\sim 73^{\circ} 30^{\prime} \mathrm{S}$. This boundary coincides with downflow change to very uniform bedforms, which suggest a uniform basal dynamic regime, probably involving an extensive basal till layer (Fig DR3B; cf. Alley et al., 1986; Dowdeswell et al., 2004). However, the new data presented here leave little doubt there was streaming flow much farther south that continued until a late stage during the last glacial cycle.

Many channels observed in the inner part of the Getz B trough and near the flanks of the Getz $A$ and Dotson troughs have undulating thal- wegs and run into shallower water depths with increasing distance offshore. These characteristics indicate that they were formed by subglacial water flow, like similar features in Pine Island Bay (Lowe and Anderson 2002, 2003), Marguerite trough (Ó Cofaigh et al., 2002), Palmer Deep (Domack et al., 2006), and Wright Valley in the Transantarctic Mountains (Lewis et al., 2006). The extent and size of the channels indicate that there have been times of abundant subglacial meltwater supply in this area, but over what period and how frequently flows occurred, how water flowed farther offshore where obvious channels are lacking, and what happened to the meltwater bedload, are all unresolved questions (Smith et al., 2009).

Within the tributary troughs, mega-scale glacial lineations are interspersed with drumlins, scoured bedrock highs, and channeled areas, and mega-scale glacial lineations are disrupted by bands of drumlins several times along some paleo-flow lines. The close spatial association and alternation of these different types of bedforms makes it implausible that they could result from substantial spatial variations in paleo-ice 
flow velocity. The high spatial variability suggests a complex ice stream basal regime, probably involving patches of dilated, deforming till interspersed with basal sliding over so-called "sticky spots" (Stokes et al., 2007) and areas of channelized subglacial meltwater flow. This interpretation is consistent with results of geophysical investigations of conditions at the base of several modern ice streams, including Rutford Ice Stream (Smith, 1997; Smith et al., 2007; King et al., 2007), Talutis Inlet (Vaughan et al., 2003), and Pine Island Glacier (Smith and Scott, 2007). The extensive area covered by the data presented here suggests that such complex basal regimes cannot be dismissed as exceptions, and therefore reliable prediction of the future behavior of modern ice streams may require collection of extensive geophysical data to map their bed conditions. Furthermore, although there are few data on geological structure beneath the WAIS, what little information exists suggests the substrate is likely to be variable (e.g., Bentley and Clough, 1972), and therefore more similar to the inner shelf area studied here than areas further offshore that are underlain by extensive sedimentary strata.

The extensive new data presented here from a zone of paleo-ice stream convergence and acceleration show that downflow progression of bedform types is not necessarily as simple as proposed by Wellner et al. (2001, 2006). High local variability suggests that the main controls on bed morphology in this largely bedrockfloored, inner shelf area are spatial variations in basal processes and resistance of the bedrock to erosion, rather than flow velocity. This in turn implies that caution must be exercised in inferring paleo-flow rates from relict bedforms alone. While mega-scale glacial lineations are a reliable indication of intermediate to fast flow, the absence of elongated bedforms does not necessarily indicate slow flow, and there is a substantially increased risk of past flow regimes being misinterpreted if data coverage is only partial.

\section{ACKNOWLEDGMENTS}

This work was supported by the Alfred Wegener Institute for Polar and Marine Research (AWI) Marine, Coastal and Polar Systems (MARCOPOLI) programs MAR2 and POL6, and the British Antarctic Survey Glacial Retreat in Antarctica and Deglaciation of the Earth System program. We thank the captains, officers, crew, technical support staff, and other scientists who participated in the two research cruises. We particularly thank Steffen Gauger for processing the Hydrosweep data collected on RV Polarstern. RVIB Nathaniel B. Palmer multibeam echo-sounding data were obtained from the Lamont multibeam synthesis. We are grateful to Eugene Domack, Phil O'Brien, and an anonymous reviewer for constructive reviews.

\section{REFERENCES CITED}

Alley, R.B., Blankenship, D.D., Bentley, C.R., and Rooney, S.T., 1986, Deformation of till beneath ice stream B: West Antarctica: Nature, v. 322, p. 57-59, doi: $10.1038 / 322057 \mathrm{a} 0$.
Bamber, J.L., Alley, R.B., and Joughin, I., 2007, Rapid response of modern day ice sheets to external forcing: Earth and Planetary Science Letters, v. 257, p. 1-13, doi: 10.1016/j.epsl.2007.03.005.

Barnes, P.W., and Lien, R., 1988, Icebergs rework shelf sediments to $500 \mathrm{~m}$ off Antarctica: Geology, v. 16, p. 1130-1133, doi: 10.1130/00917613(1988)016<1130:IRSSTM>2.3.CO;2.

Bentley, C.R., and Clough, J.W., 1972, Antarctic subglacial structure from seismic refraction measurements, in Adie, R.J., ed., Antarctic geology and geophysics: Oslo, Universitetsforlaget, p. 683-691

Canals, M., Urgeles, R., and Calafat, A.M., 2000, Deep sea-floor evidence of past ice streams off the Antarctic Peninsula: Geology, v. 28, p. 3134, doi: 10.1130/0091-7613(2000)028<0031: DSEOPI $>2.0 . \mathrm{CO} ; 2$.

Domack, E., Amblàs, D., Gilbert, R., Brachfeld, S., Camerlenghi, A., Rebesco, M., Canals, M., and Urgeles, R., 2006, Subglacial morphology and glacial evolution of the Palmer deep outlet system, Antarctic Peninsula: Geomorphology, v. 75 , p. $125-142$.

Dowdeswell, J.A., Ó Cofaigh, C., and Pudsey, C.J., 2004, Thickness and extent of the subglacial till layer beneath an Antarctic paleo-ice stream: Geology, v. 32, p. 13-16.

Engelhardt, H., and Kamb, B., 1998, Basal sliding of Ice Stream B, West Antarctica: Journal of Glaciology, v. 44, p. 223-230.

Evans, J., Dowdeswell, J.A., Ó Cofaigh, C., Benham, T.J., and Anderson, J.B., 2006, Extent and dynamics of the West Antarctic Ice Sheet on the outer continental shelf of Pine Island Bay during the last glaciation: Marine Geology, v. 230, p. 53-72, doi: 10.1016/j.margeo.2006.04.001.

Hughes, T.J., 1981, The weak underbelly of the West Antarctic ice sheet: Journal of Glaciology, v. 27, p. 518-525.

Intergovernmental Panel on Climate Change, 2007, Climate change 2007: The physical science basis-Summary for policy makers: IPCC Secretariat, Geneva, Switzerland, http://www.ipcc. ch/pdf/assessment-report/ar4/syr/ar4_syr_spm. pdf (January 2009).

King, E.C., Woodward, J., and Smith, A.M., 2007, Seismic and radar observations of subglacial bed forms beneath the onset zone of Rutford Ice Stream, Antarctica: Journal of Glaciology, v. 53, p. 665-672, doi: 10.3189/002214307784409216.

Larter, R.D., and 14 others, 2007, West Antarctic Ice Sheet change since the Last Glacial Period: Eos (Transactions, American Geophysical Union), v. 88, p. 189-190, doi: 10.1029/2007EO170001.

Lewis, A.R., Marchant, D.R., Kowalewski, D.E., Baldwin, S.L., and Webb, L.E., 2006, The age and origin of the Labyrinth, western Dry Valleys, Antarctica: Evidence for extensive middle Miocene subglacial floods and freshwater discharge to the Southern Ocean: Geology, v. 34, p. 513-516, doi: 10.1130/G22145.1.

Lowe, A.L., and Anderson, J.B., 2002, Reconstruction of the West Antarctic ice sheet in Pine Island Bay during the Last Glacial Maximum and its subsequent retreat history: Quaternary Science Reviews, v. 21, p. 1879-1897, doi: 10.1016/ S0277-3791(02)00006-9.

Lowe, A.L., and Anderson, J.B., 2003, Evidence for abundant subglacial meltwater beneath the paleo-ice sheet in Pine Island Bay, Antarctica: Journal of Glaciology, v. 49, p. 125-138, doi: 10.3189/172756503781830971.

Nitsche, F.O., Jacobs, S.S., Larter, R.D., and Gohl, K., 2007, Bathymetry of the Amundsen Sea continental shelf: Implications for, geology, oceanography and glaciology: Geochemistry, Geophysics, Geosystems, v. 8, Q10009, doi: 10.1029/2007GC001694.

O'Brien, P.E., De Santis, L., Harris, P.T., Domack, E., and Quilty, P.G., 1999, Ice shelf grounding zone features of western Prydz Bay, Antarctica: Sedimentary processes from seismic and sidescan images: Antarctic Science, v. 11, p. 78-91, doi: 10.1017/S0954102099000115.

Ó Cofaigh, C., Pudsey, C.J., Dowdeswell, J.A., and Morris, P., 2002, Evolution of subglacial bedforms along a paleo-ice stream, Antarctic Peninsula continental shelf: Geophysical Research Letters, v. 29, p. 41-1-41-4, doi: 10.1029/2001GL014488.

Pudsey, C.J., Barker, P.F., and Larter, R.D., 1994, Ice sheet retreat from the Antarctic Peninsula shelf: Continental Shelf Research, v. 14, p. 1647-1675, doi: 10.1016/0278-4343(94)90041-8.

Shipp, S.,Anderson, J., and Domack,E., 1999, Late Pleistocene-Holocene retreat of the West Antarctic Ice Sheet system in the Ross Sea: Part 1—Geophysical results: Geological Society of America Bulletin, v. 111, p. 1486-1516, doi: 10.1130/0016-7606 (1999) 111<1486:LPHROT>2.3.CO;2.

Smith, A.M., 1997, Variations in basal conditions on Rutford Ice Stream, West Antarctica: Journal of Glaciology, v. 43, p. 245-255.

Smith, A., and Scott, J., 2007, Basal conditions on Pine Island Glacier: 2007 WAIS/FRISP Workshop (14th Annual WAIS) Agenda and Abstracts: http://neptune.gsfc.nasa.gov/wais/pastmeetings/ abstracts07/SmithA.pdf (January 2009).

Smith, A.M., Murray, T., Nicholls, K.W., Makinson, K., Ađalgeirsdottir, G., Behar, A.E., and Vaughan, D.G., 2007, Rapid erosion, drumlin formation, and changing hydrology beneath an Antarctic ice stream: Geology, v. 35, p. 127-130, doi: 10.1130/ G23036A.1.

Smith, J.A., Hillenbrand, C.-D., Larter, R.D., Graham, A.G.C., and Kuhn, G, 2009, The sediment infill of subglacial meltwater channels on the West Antarctic continental shelf: Quaternary Research, v. 71, p. 190-200 , doi: 10.1016/j.yqres.2008.11.005.

Stokes, C.R., and Clark, C.D., 2002, Are long subglacial bedforms indicative of fast ice flow?: Boreas, v. 31, p. 239-249, doi: 10.1080/030094802760260355.

Stokes, C.R., Clark, C.D., Lian, O.B., and Tulaczyk, S., 2007, Ice stream sticky spots: A review of their identification and influence beneath contemporary and palaeo-ice streams: Earth-Science Reviews, v. 81, p. 217-249.

Vaughan, D.G., 2008, West Antarctic Ice Sheet collapse-The fall and rise of a paradigm: Climatic Change, v. 91, p. 65-79, doi: 10.1007/s10584008-9448-3.

Vaughan, D.G., Smith, A.M., Nath, P.C., and LeMeur, E., 2003, Acoustic impedance and basal shear stress beneath four Antarctic ice streams: Annals of Glaciology, v. 36, p. 225-232, doi: 10.3189/172756403781816437.

Wellner, J.S., Lowe, A.L., Shipp, S.S., and Anderson, J.B., 2001, Distribution of glacial geomorphic features on the Antarctic continental shelf and correlation with substrate: Implications for ice behaviour: Journal of Glaciology, v. 47, p. $397-$ 411, doi: 10.3189/172756501781832043.

Wellner, J.S., Heroy, D.C., and Anderson, J.B., 2006, The death mask of the Antarctic ice sheet: Comparison of glacial geomorphic features across the continental shelf: Geomorphology, v. 75, p. 157 171, doi: 10.1016/j.geomorph.2005.05.015.

Manuscript received 22 September 2008

Revised manuscript received 9 December 2008

Manuscript accepted 14 December 2008

Printed in USA 